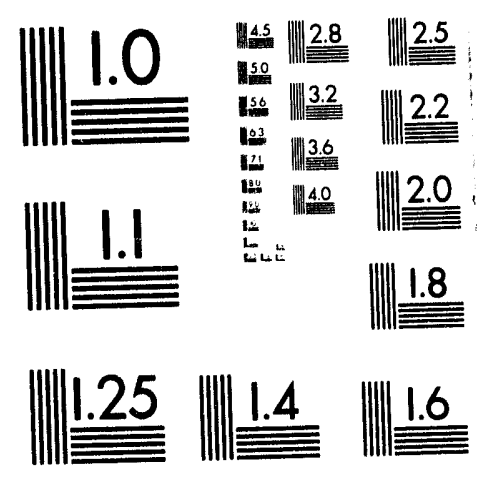



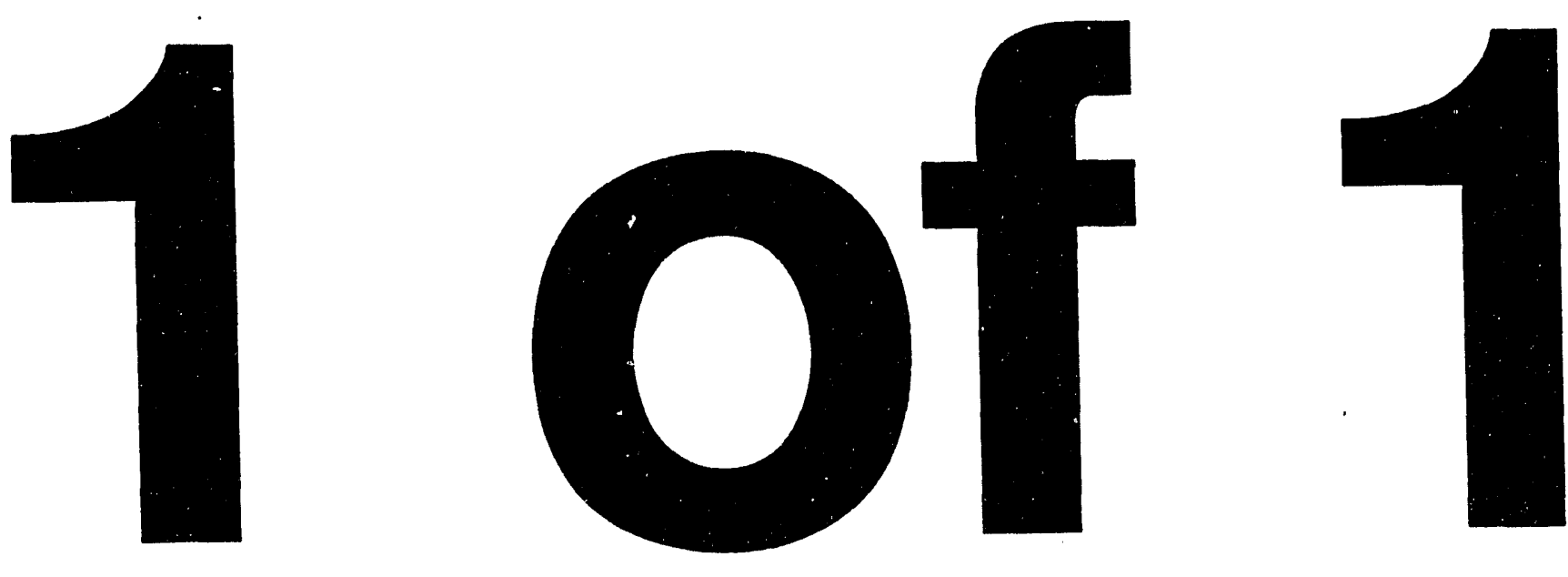
WSRC-TR-93-669

Rev 0

\section{Toxicity Test of the F-Area Seep Soils by Laboratory Lettuce Seed Germination and Seedling Growth ${ }^{(U)}$}




\section{Disclaimer}

This report was prepared as an account of work sponsored by an agency of the United States Government. Neither the United States Government nor any agency thereof, nor any of their employees, makes any warranty, express or implied, or assumes any legal liability or responsibility for the accuracy, completeness, or usefulness of any information, apparatus, product, or process disclosed, or represents that its use would not infringe privately owned rights. Reference herein to any specific commercial product, process, or service by trade name, trademark, manufacturer, or otherwise does not necessarily constitute or imply its endorsement, recommendation, or favoring by the United States Government or any agency thereof. The views and opinions of authors expressed herein do not necessarily state or reflect those of the United States Government or any agency thereof. 
WSRC-TR-93-669

$\operatorname{Rev} 0$

September 1993

\section{Toxicity Test of the F-Area Seep Soils by Laboratory Lettuce Seed Germination and Seedling Growth $(U)$}

D. Eaton and C. E. Murphy

Prepared for the U.S. Department of Energy under contract no. DE-AC09-89SR18035 


\title{
Toxicity Test of the F-Area Seep Soils by Laboratory Lettuce Seed Germination and Seedling Growth
}

\author{
D. Eaton and C. E. Murphy
}

\begin{abstract}
This study is a follow-up of a similar study done by Loehle (1990). The objectives of the original study were to: (1) measure the toxicity of groundwater contaminated by the F-Area seepage basins where this water surfaces in a seepline along Fourmile Branch and (2) to evaluate the effectiveness of rainwater for washing contaminants from the soil. Results of seed germination tests show no significant difference between water extracted from one extraction of F-Area seepline soil, soil from a control area, the sixth consecutive extraction from F-Area soil, and a deionized water control. A root-growth assay on the same seeds shows a significant effect with the order of growth, first extraction of F-Area soil<control site<deionized water<sixth F-Area extraction. When compared to the results of the 1990 study, this suggests that there may be some improvement in the soil at the F-Area seepline, but there is still some evidence of phytotoxicity in this soil. As shown previously, the cause of the toxicity is removed by soil washing, suggesting that continued improvement should be expected.
\end{abstract}

\section{Introduction}

The F-Area Seepline is located along Fourmile Branch (Figure 1). The seepline is an area of springs where groundwater surfaces and produces swamps and small tributaries that empty into the adjacent creek. Seeplines occur naturally along Fourmile Branch. However, it was realized quite early that some of the springs along Fourmile Branch were receiving water from the seepage basins used for disposal of low-level waste water from the F- and H-Area chemical separations facilities. Tree mortality has been observed along these seeplines and the adjacent swamps (Killian et al. 1987, Mackey 1988).

Low-level liquid waste was released to the F- and H-Area seepage basins from the mid-1950s until 1988 when the basins were filled and covered with an impervious clay cap. The waste water entering the basins was typically acidic, high in dissolved ions, and contained low levels of radionuclides and dissolved metals (Killian et al. 1987). Seepline water contained elevated levels of sodium, nitrate, aluminum, and heavy metals. Elevated aluminum concentrations were also found, probably the product of leaching from the clay soil matrix by the acidic water.

Loehle (1990) conducted toxicity tests of soil collected earlier from the F-Area seepline for chemical and physical characterization (Richardson et al. 1990). The tests were designed to assess toxicity before and after leaching of the soil by rainwater. The tests described in this paper were designed to evaluate changes in toxicity over the threeyear period since Loelhe's (1990) study. These tests were done on the same F-Area seepline soil used in the Loehle (1990) study, collected from (as closely as possible) the same location.

\section{Methods}

The methods used in this study duplicated, as closely as practical, those used by Loehle (1990). These methods were originally described by Carlson et al. (1989). Soils were gathered from two locations, adjacent to field marker in the F-Area seepline and at a control site in the flood plain of Fourmile Branch near its crossing with SRS Road E-1. The latter site is upstream of the seeplines contaminated by the F- and $\mathrm{H}$-Area seepage basin effluents.

Samples were taken by digging three trench at each site to 18 inches and collecting a slice of soil that was of equal volume for each depth from 0 to 18 inches. The soil contained considerable organic material near the surface but graded to more mineral soil with depth.

The soil samples were removed to the laboratory where they were put in individual stainless steel pans and dried in an oven at $45^{\circ} \mathrm{C}$ until repeated weighing showed no fur- 
ther weight loss. Water extractions were done by putting $100 \mathrm{gm}$ of dry soil in a $250 \mathrm{~mL}$ polyethylene bottle and adding $150 \mathrm{~mL}$ of deionized water. The soil-water mixture was shaken five times initially and five times once each day for four days. After the mixture had been allowed to cquilibrate for four days, it was placed in a centrifuge and the water and soil separated. The water was decanted from the bottle and filter to remove any remaining suspended soil. At the end of the first four days there were six water samples from the soils, three from the F-Area seepline and three from the control area. The water samples were stored in a refrigerator until used.

The F-Area seepline soil was extracted five more times. The same sequence of adding water, shaking, and equilibrating for fours days was used for each extraction. Only $100 \mathrm{~mL}$ of water was added for these extraction rather than the $150 \mathrm{~mL}$ used in the first extraction. The soil samples were not dried between extractions. Only the water from the sixth set of extractions was saved. At the end of the extraction there were nine water samples, three from a single extraction from the control, three from a single extraction from the F-Area seepline samples, and three from the sixth extraction of the F-Area seepline samples.

Four water samples were prepared for toxicity testing. Water samples were prepared by mixing equal quantities of water from the three samples of each extraction type, control (C), first F-Area seepline extraction (F1), and sixth F-Area seepline extraction (F6). A deionized water sample was also prepared.

Filter papers $(9 \mathrm{~mm})$ were placed in $10 \mathrm{~mm}$ diameter petri dishes. Eight petri dishes were prepared for each type of water (total of 32 dishes). The petri dishes were on a table lop near the window of the laboratory. The treatment (type of water added) used in each petri dish was randomly sclected so that distance from the window would not be a factor. The filter paper in the petri dish was saturated with one of the types of water. Ten lettuce seeds were placed on the filter paper; the variety butter crunch bib was used. The tops were placed on the petri dishes and they were sealed with wax.

The seeds were allowed to germinate for three days. At the cnd of this period the germinated seeds were removed from the petri dishes and an image was recorded with a copy machine. Ungerminated seeds were not copied. The number of seeds germinating in each petri dish were counted. The length of the roots of the germinated seedlings was measured by using a line distance recorder run along the roots images.

\section{Results}

The results of the germination test are shown in Table 1 and Figure 2. An analysis of variance procedure was carried out on this data (Table 4). As is obvious from the data, there was no significant effect of the treatments. Even though the germination of the seeds exposed to water from the first extraction of the F-Area seepline soil is lower than the control or any of the other treatments, the difference is too small to be differentiated from random chance.

The results of the root-length measurements are shown in Table 2 and Figure 3. Unlike the seed germination, the root length does appear to be affected by the type of treatment. This is confirmed by an analysis of variance procedure, which shows significant treatment effects (Table 5). Comparison of the $95 \%$, two-tailed confidence limits for each treatment indicates significant differences in treatments with the first extraction from F-Area seepline soil being significantly lower in length than any other treatment. However, it should be noted that the water extracted from the control soil also shows significant depression of root growth when compared to either the water from the sixth extraction from the F-Area seepline soil or deionized water. This suggests that there is toxicity to lettuce seedlings even in uncontaminated forest soils. This should not be tou surprising since allelopathy (chemical competition) is common among forest tree species.

\section{Discussion}

When the results of this study are compared to the earlier study of Loehle, there does appear to be some decrease in toxicity (Table 3 ). This is shown most clearly in the secd germination studies. This is in agreement with the recovery of the die-back area from which the samples were collected at the F-Area secpline. While trees have not begun to grow in this area there are a number of herbaccous species which have begun to colonize this area.

The confirmation that the toxic agent(s) in the soil can be removed by successive washes, the decrease in toxicity to lettuce seed, and the revegetation of the area all suggest that the area will recover naturally given time for the toxic agent(s) to leach from the soil. 


\section{References}

Carlson, C.L., D.I. Kaplan, and D.C. Adriano, 1989. Effects of Selenium on Germination and Radicle Elongation of Selected Agronomic Species. Environmental and Experimental Botany 4: 493-498.

Killian, T. H., H. L. Colb, P. Corbo, and I. W. Marine. 1987. Environmental Information Document F-Area Seepage Basins. DPST-87-704, E.I. du Pont de Nemours and Co., Inc., Savannah River Laboratory, Aiken, $\mathrm{SC}$.
Loehle, C. 1990. Recovery of Contaminated Wetland Soils at SRS by Natural Rainfall: An Experimental, Toxicological Study. WSRC-RD-90-14. Westinghouse Savannah River Company, Savannah River Site, Aiken, SC,

Mackey, Jr., H. E. 1988. Initial Evaluation of Photographic Data of F- and H-Area Seepage Basin Outcrops. SPST-88-314. E.I. du Pont de Nemours and Co., Inc., Savannah River Laboratory, Aiken, SC.

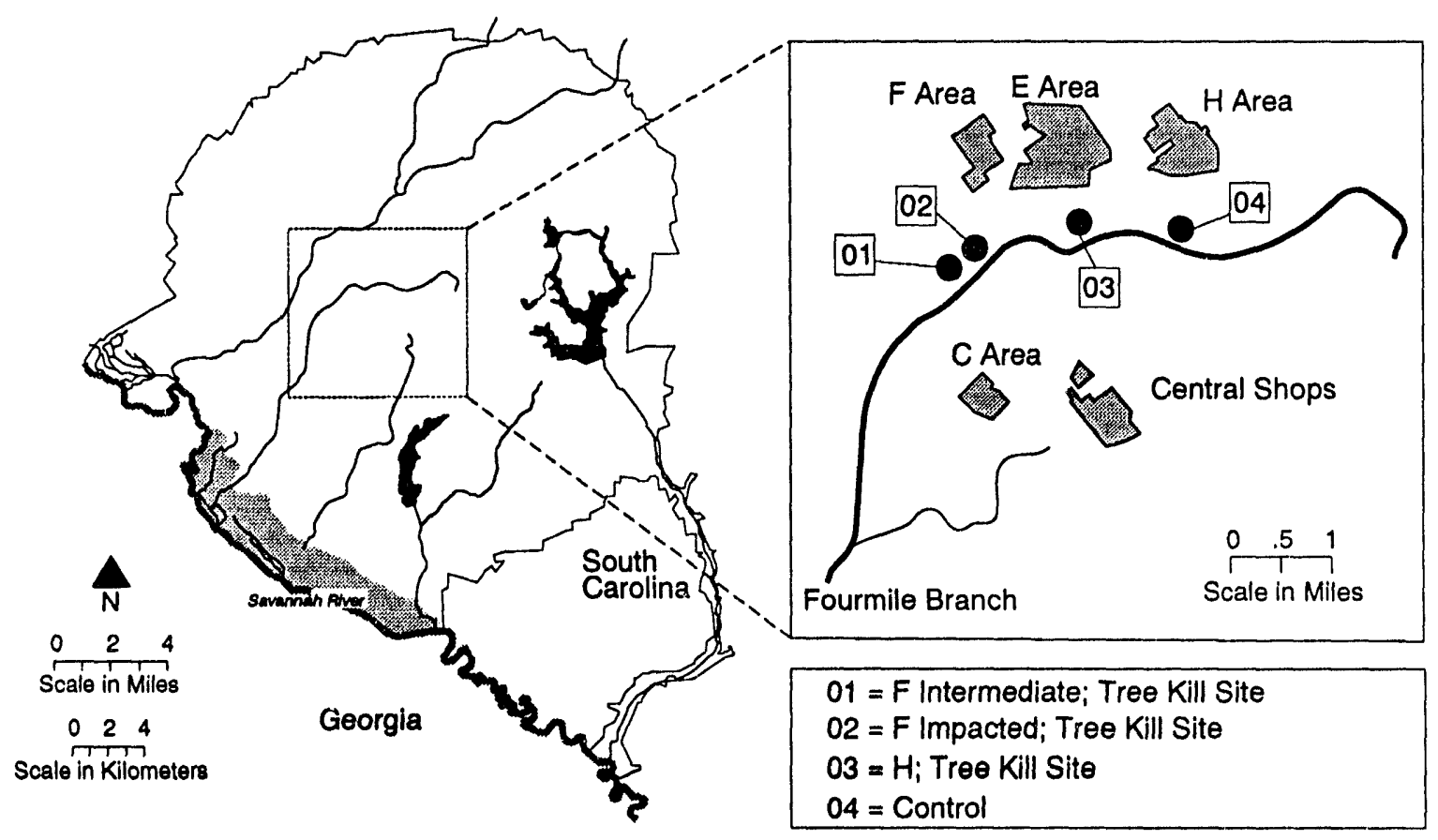

Figure 1. Map of study site locations at SRS 


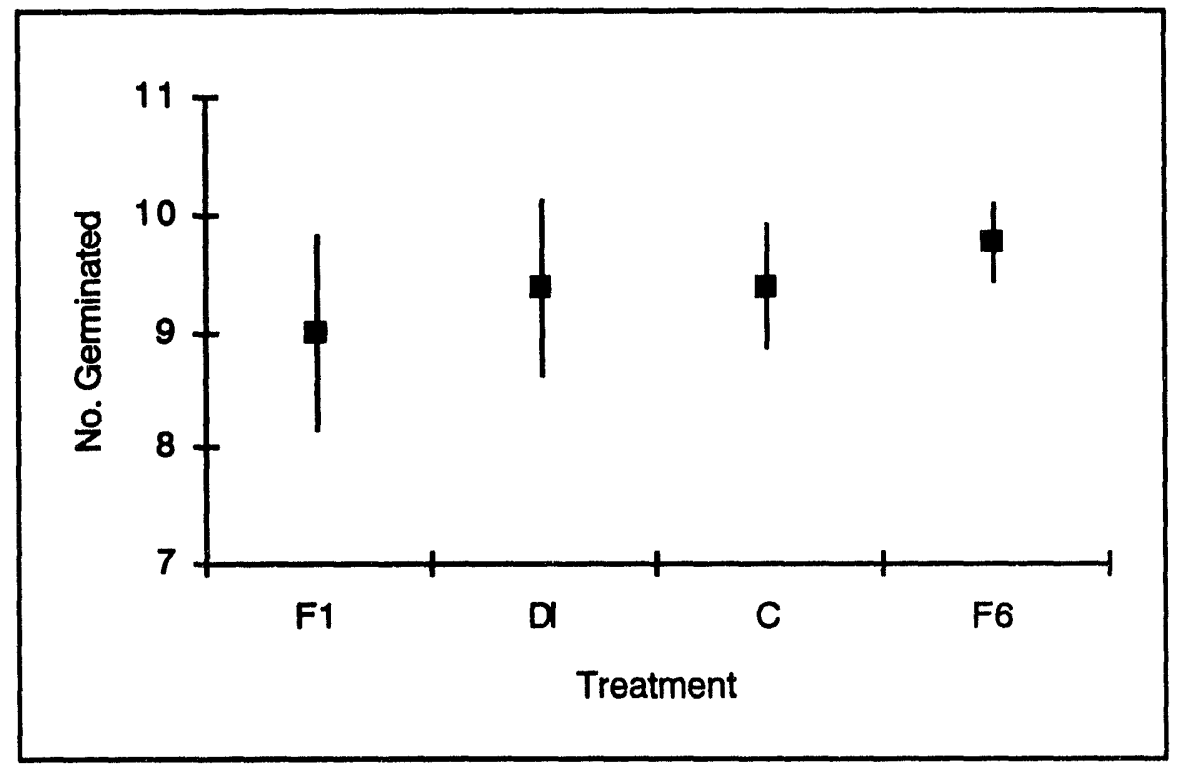

Figure 2. Germination of Lettuce Seed. Vertical Line spans $95 \%$ Confidence Limits of Mean. Square is at the Mean Germination for Eight Petri Dishes.

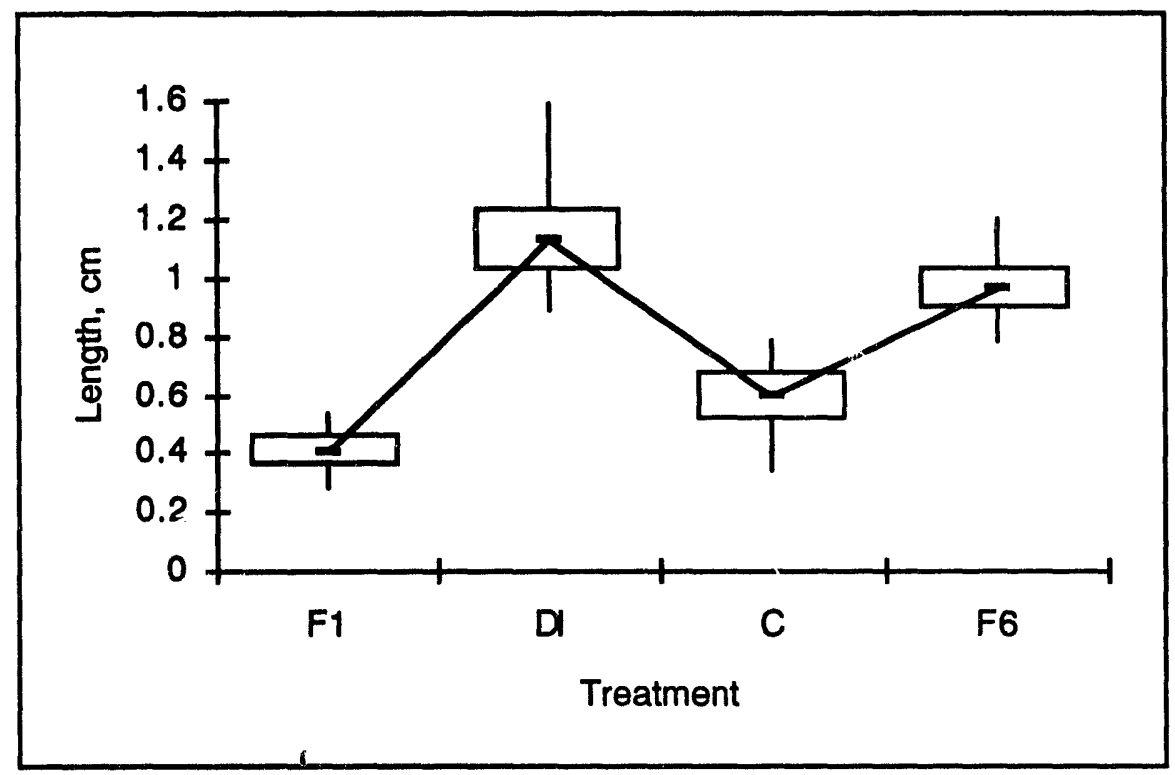

Figure 3. Results of Lettuce Seedling Root Growth. Vertical line spans middle 50 percentile. Box spans $95 \%$ Confidence limits. Bars connected by line are at the mean length. 
Table 1. Lettuce Seed Germination in Water from Different Sources.

Petri Dish Number (Randomly Assigned)

\begin{tabular}{lrrrrrrrr}
\multicolumn{1}{c}{ Treatment } & D1 & D2 & D3 & D4 & D5 & D6 & D7 & D8 \\
\hline F-Area, First Wash & $\mathbf{8}$ & $\mathbf{8}$ & $\mathbf{7}$ & 10 & 9 & 10 & 10 & 10 \\
Deionized Water & 10 & 10 & 10 & 9 & 10 & 10 & 7 & 9 \\
Control & 10 & 10 & 10 & 8 & 9 & 9 & 9 & 10 \\
F-Area, Sixth Wash & 10 & 10 & 9 & 10 & 10 & 10 & 10 & 9
\end{tabular}

Table 2. Root Growth in Water from Different Sources (cm).

Petri Dish Number (Randomly Assigned)

\begin{tabular}{|c|c|c|c|c|c|c|c|c|}
\hline & D1 & D2 & D3 & D4 & D5 & D6 & D7 & D8 \\
\hline F-Area, First Wash & 0.41 & 0.44 & 0.19 & 0.41 & 0.03 & 0.98 & 0.67 & 0.48 \\
\hline F-Area, First Wash & 0.38 & 0.54 & 0.29 & 0.32 & 0.35 & 0.29 & 0.73 & 0.32 \\
\hline F-Area, First Wash & 0.32 & 0.57 & 0.38 & 0.54 & 0.29 & 0.38 & 0.95 & 0.32 \\
\hline F-Area, First Wash & 0.35 & 0.57 & 0.38 & 0.38 & 0.26 & 0.51 & 0.48 & 0.54 \\
\hline F-Area, First Wash & 0.32 & 1.33 & 0.29 & 0.26 & 0.26 & 0.67 & 0.63 & 0.54 \\
\hline F-Area, First Wash & 0.16 & 0.41 & 0.48 & 0.44 & 0.29 & 0.67 & 0.41 & 0.63 \\
\hline F-Area, First Wash & 0.35 & 0.44 & 0.35 & 0.51 & 0.19 & 0.57 & 0.32 & 0.54 \\
\hline F-Area, First Wash & 0.48 & 0.6 & 0 & 0.07 & 0.26 & 0.7 & 0.56 & 0.57 \\
\hline F-Area, First Wash & 0 & 0 & 0 & 0.26 & 0.32 & 0.54 & 0.22 & 0.73 \\
\hline F-Area, First Wash & 0 & 0 & 0 & 0.57 & 0 & 0.48 & 0.67 & 0.7 \\
\hline Deionized Water & 1.77 & 0.82 & 0.98 & 1.33 & 1.3 & 1.08 & 1.08 & 1.08 \\
\hline Deionized Water & 1.08 & 0.89 & 1.11 & 1.58 & 1.49 & 1.01 & 1.42 & 0.98 \\
\hline Deionizcd Water & 1.33 & 0.95 & 1.68 & 1.65 & 1.14 & 1.52 & 1.68 & 1.14 \\
\hline Deionized Water & 1.65 & 0.89 & 1.2 & 1.68 & 0.35 & 0.73 & 1.65 & 1.68 \\
\hline Deionized Water & 1.61 & 1.05 & 1.84 & 1.39 & 0.38 & 1.61 & 1.71 & 0.98 \\
\hline Deionized Water & 0.48 & 0.38 & 0.19 & 0.67 & 1.08 & 1.49 & 0.26 & 1.58 \\
\hline Deionized Water & 1.61 & 0.89 & 1.11 & 1.74 & 1.3 & 1.71 & 0.76 & 1.27 \\
\hline Deionized Water & 1.08 & 1.05 & 1.33 & 1.58 & 1.96 & 1.08 & 0 & 0.89 \\
\hline Deionized Water & 1.27 & 0.73 & 1.61 & 1.33 & 1.65 & 1.14 & 0 & 1.23 \\
\hline Deionized Water & 1.33 & 0.79 & 1.2 & 0 & 1.17 & 1.27 & 0 & 0 \\
\hline Control & 0.6 & 0.76 & 0.48 & 0.6 & 0.76 & 0.35 & 1.3 & 1.46 \\
\hline Control & 0.26 & 0.44 & 0.6 & 0.76 & 0.95 & 0.19 & 0.67 & 1.23 \\
\hline Control & 0.76 & 0.73 & 0.57 & 0.63 & 0.35 & 0.38 & 1.01 & 1.17 \\
\hline Control & 0.41 & 0.86 & 1.14 & 0.29 & 0.92 & 0.35 & 0.98 & 1.39 \\
\hline Control & 0.41 & 0.89 & 1.14 & 0.29 & 0.41 & 1.17 & 1.42 & 1.48 \\
\hline Control & 1.05 & 0.26 & 0.26 & 0.26 & 0.38 & 0.07 & 0.26 & 0.22 \\
\hline Control & 0.67 & 0.38 & 0.7 & 0.73 & 0.38 & 0.38 & 0.35 & 0.76 \\
\hline Control & 0.31 & 0.13 & 0.38 & 0.76 & 0.51 & 0.26 & 0.48 & 0.89 \\
\hline Control & 0.41 & 0.38 & 0.6 & 0 & 0.38 & 0.38 & 1.23 & 0.6 \\
\hline Control & 0.76 & 0.38 & 0.51 & 0 & 0 & 0 & 0 & 0.95 \\
\hline F-Area, Sixth Wash & 0.82 & 1.01 & 0.82 & 0.76 & 0.98 & 1.71 & 0.92 & 1.36 \\
\hline F-Area, Sixth Wash & 1.01 & 0.51 & 0.88 & 0.82 & 1.52 & 1.49 & 1.27 & 0.86 \\
\hline F-Area, Sixth Wash & 1.07 & 0.82 & 0.88 & 1.23 & 0.82 & 1.2 & 1.01 & 0.89 \\
\hline F-Area, Sixth Wash & 0.38 & 0.88 & 0.82 & 0.76 & 1.08 & 0.92 & 0.98 & 1.36 \\
\hline F-Arca, Sixth Wash & 0.32 & 0.95 & 0.38 & 1.2 & 0.76 & 1.01 & 1.23 & 1.33 \\
\hline F-Area, Sixth Wash & 1.01 & 0.95 & 0.51 & 1.2 & 0.44 & 1.55 & 0.98 & 1.71 \\
\hline F-Area, Sixth Wash & 0.63 & 0.95 & 0.57 & 1.08 & 0.54 & 1.14 & 0.73 & 1.23 \\
\hline F-Area, Sixth Wash & 0.76 & 1.07 & 0.88 & 0.92 & 1.39 & 0.63 & 0.79 & 1.42 \\
\hline F-Area, Sixth Wash & 0.82 & 1.14 & 0.7 & 1.05 & 1.11 & 1.3 & 1.2 & 0.51 \\
\hline F-Area, Sixth Wash & 0.57 & 1.33 & 0 & 1.2 & 1.36 & 1.49 & 0.98 & 0 \\
\hline
\end{tabular}


Table 3. Comparison of 1990 and 1993 Toxicity Tests.

\begin{tabular}{lcccc} 
& \multicolumn{2}{c}{ Germination } & \multicolumn{2}{c}{ Length $(\mathbf{c m})$} \\
\multicolumn{1}{c}{ Treatment } & 1990 & 1993 & 1990 & 1993 \\
\hline F-Area, First Wash & 4.4 & 9 & 0.76 & 0.41 \\
Deionized Water & 9.5 & 9.375 & 1.22 & 1.13 \\
Control & 7.5 & 9.375 & 1.18 & 0.6 \\
F-Area, Sixth Wash & 8.5 & 9.75 & 1.03 & 0.96
\end{tabular}

Table 4. Analysis of Variance Table for Seed Germination

Anova: Single-Factor

Summary

\begin{tabular}{|c|c|c|c|c|c|}
\hline & Groups & Count & Sum & Average & Variance \\
\hline F-Area, First Wash & & 8 & 72 & 9 & 1.428571 \\
\hline Deionized Water & & 8 & 75 & 9.375 & 1.125 \\
\hline Control & & 8 & 75 & 9.375 & 0.553571 \\
\hline F-Area, Sixth Wash & & 8 & 78 & 9.75 & 0.214286 \\
\hline
\end{tabular}

ANOVA

Source of Variation

$\begin{array}{lcclcrr} & \text { SS } & \text { df } & \text { MS } & \text { F } & \text { P-value } & \text { F crit } \\ \text { Between Groups } & 2.25 & 3 & 0.75 & 0.903226 & 0.452 & 2.947 \\ \text { Within Groups } & 23.25 & 28 & 0.83036 & & & \\ \text { Total } & 25.5 & 31 & & & & \end{array}$


Table 5. Analysis of Variance Table for Root Growth Toxicity Test

Anova: Two-Factor With Replication

Summary

\begin{tabular}{|c|c|c|c|c|c|c|c|c|c|}
\hline & D1 & D2 & D3 & D4 & D5 & D6 & D7 & D8 & Total \\
\hline \multicolumn{10}{|l|}{$\overline{F 1}$} \\
\hline Count & 10 & 10 & 10 & 10 & 10 & 10 & 10 & 10 & 80 \\
\hline Sum & 2.76 & 4.89 & 2.345 & 3.73 & 2.22 & 5.755 & 5.615 & 5.335 & 32.65 \\
\hline Average & 0.276 & 0.489 & 0.2345 & 0.373 & 0.222 & 0.5755 & 0.5615 & 0.5335 & 3.265 \\
\hline Variance & 0.0276 & 0.1351 & 0.0317 & 0.0238 & 0.0137 & 0.037 & 0.0457 & 0.0189 & 0.334 \\
\hline \multicolumn{10}{|l|}{ DI } \\
\hline Count & 10 & 10 & 10 & 10 & 10 & 10 & 10 & 10 & 80 \\
\hline Sum & 13.175 & 8.41 & 12.225 & 12.925 & 11.79 & 12.6 & 8.535 & 10.805 & 90.47 \\
\hline Average & 1.3175 & 0.841 & 1.2225 & 1.2925 & 1.179 & 1.26 & 0.8535 & 1.0805 & 9.047 \\
\hline Variance & 0.1459 & 0.0367 & 0.2105 & 0.3013 & 0.254 & 0.0966 & 0.5499 & 0.2098 & 1.805 \\
\hline \multicolumn{10}{|l|}{ C } \\
\hline Count & 10 & 10 & 10 & 10 & 10 & 10 & 10 & 10 & 80 \\
\hline Sum & 5.625 & 5.185 & 6.35 & 4.3 & 5.03 & 3.52 & 7.68 & 10.14 & 47.83 \\
\hline Average & 0.5625 & 0.5185 & 0.635 & 0.43 & 0.503 & 0.352 & 0.768 & 1.014 & 4.783 \\
\hline Variance & 0.0612 & 0.0707 & 0.0847 & 0.0907 & 0.0851 & 0.1015 & 0.2382 & 0.1679 & 0.9 \\
\hline
\end{tabular}

Anova: Two-Factor With Replication

Summary

\begin{tabular}{|c|c|c|c|c|c|c|c|c|c|}
\hline & D1 & D2 & D3 & D4 & D5 & D6 & D7 & D8 & Total \\
\hline \multicolumn{10}{|l|}{ F6 } \\
\hline Count & 10 & 10 & 10 & 10 & 10 & 10 & 10 & 10 & 80 \\
\hline Sum & 7.39 & 9.61 & 6.44 & 10.205 & 9.98 & 12.41 & 10.075 & 10.645 & 76.76 \\
\hline Average & 0.739 & 0.961 & 0.644 & 1.0205 & 0.998 & 1.241 & 1.0075 & 1.0645 & 7.676 \\
\hline Variance & 0.0683 & 0.0459 & 0.0822 & 0.0368 & 0.1315 & 0.1087 & 0.0323 & 0.2588 & 0.765 \\
\hline
\end{tabular}

Total

$\begin{array}{lllllllll}\text { Count } & 40 & 40 & 40 & 40 & 40 & 40 & 40 & 40 \\ \text { Sum } & 28.95 & 28.095 & 27.36 & 31.16 & 29.02 & 34.285 & 31.905 & 36.925 \\ \text { Average } & 2.895 & 2.8095 & 2.736 & 3.116 & 2.902 & 3.4285 & 3.1905 & 3.6925 \\ \text { Variance } & 0.3031 & 0.2883 & 0.4091 & 0.4527 & 0.4844 & 0.3438 & 0.8661 & 0.6554\end{array}$

ANOVA

Source of Variation

\begin{tabular}{lcrcccc} 
& SS & df & MS & F & P-value & F crit \\
\hline Sample & 26.127 & 3 & 8.709 & 73.284 & $3 \mathrm{E}-35$ & 2.636 \\
Column & 1.9135 & 7 & 0.2734 & 2.3003 & 0.027 & 2.0414 \\
Interaction & 7.7237 & 21 & 0.3678 & 3.0949 & $1 \mathrm{E}-05$ & 1.5927 \\
Within & 34.225 & 288 & 0.1188 & & & \\
Total & 69.99 & 319 & & & & \\
\hline
\end{tabular}




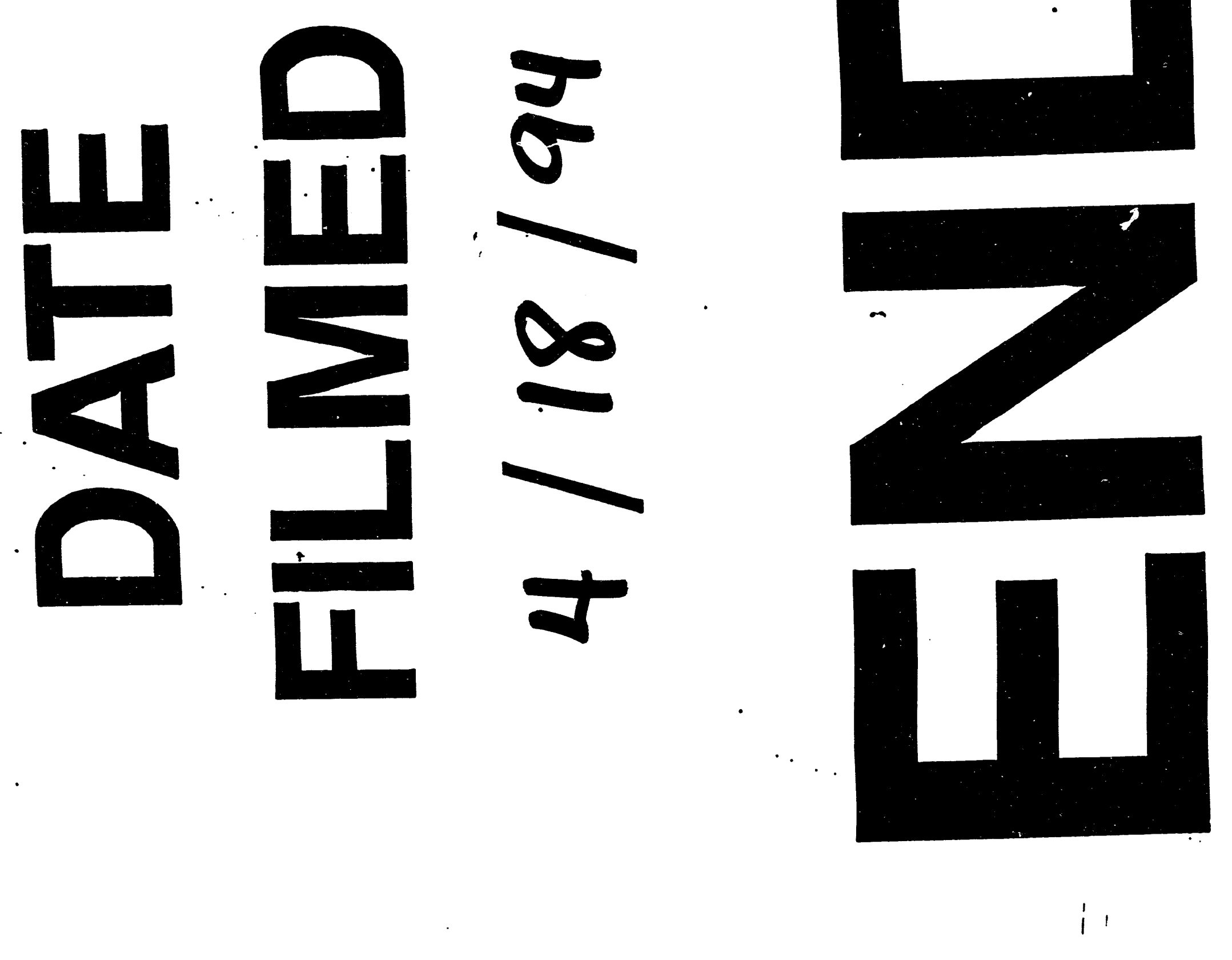

